DOI https://doi.org/10.18551/rjoas.2020-10.24

\title{
PUBLIC PERCEPTION LEVEL TOWARDS INVESTMENT AND ONE STOP INTEGRATED SERVICE OFFICE OF PAMEKASAN REGENCY ON SOLVING COMPLAINTS AND SUGGESTIONS ON GIVING LICENSE OF HOUSING AND RESIDENTIAL AREA
}

\author{
Sulistiawaty Titien, Basyarahil Abubakar, Abdurahman, Azizah Rina Nur \\ Study Program of Public Administration, Faculty of Administrative Sciences, \\ Madura University, Indonesia \\ *E-mail: titiensulistiawaty@unira.ac.id
}

\begin{abstract}
One of public service offered by Investment and One Stop Integrated Service Office is a service of getting license of housing and residential area. Some complaints and suggestions are delivered to this office for better service. This study is aimed to measure public perception level towards Investment and One Stop Integrated Service Office on solving complaints and suggestion by giving license of housing and residential area. The method used in this study was survey in reference to the Regulation of the Minister of Administrative Reform and Bureaucratic Reform of the Republic of Indonesia Number 14 of 2017 about guidelines for arranging survey of public perception unit.
\end{abstract}

\section{KEY WORDS}

Public perception, complaints, suggestions, investment, one stop integrated service.

The researcher found some discrepancies when she/he conducted a prior study about solving complaints and suggestion on giving license of housing at Investment and One Stop Integrated Service. Those problems were caused by unresponsive service given by the employees so they would affect on public perception toward this service.

One of indicators of good service it is if the employees give fast response towards public's complaints. In this case, people complain to public service if they are dissatisfied to the service given, while their complaints should be solved as fast as possible.

It is not possible for an organization to improve its service if there are some complaints from people as a public's critical attitude. By these complaints, it makes easier to analyze which part of its performance that should be improved.

Based on the problem above, the researcher wanted to do a study about public perception level towards investment and one stop integrated service office in solving complaints and suggestion on giving license of housing and residential area.

Based on the statements of the problem mentioned above, the objective of this research is, to know about public perception level towards Investment and One Stop Integrated Service Office of Pamekasan in solving complaints and suggestions on giving license of housing and residential area

The research is highly expected to give contribution to public to know the performance of Investment and One Stop Integrated Service Office at Pamekasan in solving complaints and suggestion on giving license of housing and residential area. It is also expected to be valuable references in improving the service's quality.

\section{METHODS OF RESEARCH}

This research is intended to measure public perception which is focused on solving complaints and suggestion on giving license of housing and residential area at Investment and One Stop Integrated Service at Pamekasan regency. To collect data, the researcher conducted a survey to the research sample from April up to August of 2019.

Since this research wanted to measure public perception level towards the ways of solving complaints and suggestions on giving license of housing and residential area, this 
research was conducted at Investment and One Stop Integrated Service Office of Pamekasan Regency.

The Regulation of the Minister of Administrative Reform and Bureaucratic Reform of the Republic of Indonesia Number 14 of 2017 become guidelines for arranging survey of public perception unit. It was carried out through the stages of preparation, implementation, data processing and data presentation.

Data were collected by using mix method. It is a combination of Qualitative and Quantitative method in one way (Sugiyono, 2011). This kind of method was used to get more comprehensive, valid, reliable and objective data.

Each question on the instrument in this study was scored based on Likert scale as follows: score 1 means the service has no capacity; score 2 means the service has low capacity; score 3 means the service has moderate capacity; score 4 means the service has high functional capacity.

If there are some questions that are not filled by the respondent, if will affect on the average value (NRR) of indicator of solving complaints and suggestion.

$$
\text { Average Value }=\frac{\text { total value }}{\text { total score of questionaire }}
$$

Firstly, the researcher determined a weighted average of ways of solving complaints and suggestion before calculating public perception level. From the calculation, known that those data had a same weighted average, it determined by using this following formula:

$$
\text { Weighted Average }=\frac{\text { total weights }}{\text { total elements }}=\frac{1}{1}=1
$$

Weighted average is used to obtain the value of public perception index, as the following formula:

$$
\text { Weighted Average }=\text { Average Value }(\text { NRR }) \times 1
$$

To make easier on interpretation the index of public perception that has a range between $25-100$ points, so the total value is converted into 25 as the following formula:

\section{Public Perception Level of Complaints and Suggestion = Total average value $\times 25$}

Considering that each service unit has different characteristics, and then it should make adjustment as follows:

- Adding some relevant elements to service unit that wanted to be measured;

- Giving higher point on dominant element of each service by considering that the amount point of all elements used is fixed;

- If there is no dominant element that would be ranked, each element is given a same point.

The data got from this research were analyzed by using computer program or database system, and by manual processing.

A test is valid if it measures what it claims to measure. This research wants to measure about measure public perception level towards Investment and One Stop Integrated Service Office on solving complaints and suggestion by giving license of housing and residential area so validity test was also conducted in this study.

Reliability test was also applied in this research to know how consistently the respondents' answer under the same conditions as their consistent answer affects on the result of data. If the researcher applied the same method to the same sample under the same conditions and he/she gets the same results, it means that the method of measurement is reliable. 


\section{RESULTS AND DISCUSSION}

It was shown that the total score of public perception level towards One Stop Integrated Service Office of Pamekasan Regency in solving complaints and suggestions on giving license of housing and residential area was 41 of 16 respondents.

Table 1 - Data Tabulation of public perception level towards Investment and One Stop Integrated Service Office of Pamekasan Regency in solving complaints and suggestions on giving license of housing and residential area

\begin{tabular}{|c|c|c|}
\hline Respondent's Number & Score & Category \\
\hline 1. & 2 & The service has low capacity \\
\hline 2. & 4 & The service has high functional capacity \\
\hline 3. & 4 & The service has high functional capacity \\
\hline 4. & 4 & The service has high functional capacity \\
\hline 5. & 3 & The service has moderate capacity \\
\hline 6. & 3 & The service has moderate capacity \\
\hline 7. & 3 & The service has no capacity \\
\hline 8. & 1 & The service has no capacity \\
\hline 9. & 1 & The service has moderate capacity \\
\hline 10. & 3 & No response \\
\hline 11. & 0 & The service has no capacity \\
\hline 12. & 1 & The service has high functional capacity \\
\hline 13. & 4 & No response \\
\hline 14. & 0 & The service has high functional capacity \\
\hline 15. & 4 & 41 \\
\hline 16. & &
\end{tabular}

Table 2 - Result of public perception level towards Investment and One Stop Integrated Service Office of Pamekasan Regency in solving complaints and suggestions on giving license of housing and residential area

\begin{tabular}{|c|c|c|c|}
\hline Elements & Average Value & Weighted Average & $\begin{array}{c}\text { Public Perception } \\
\text { Level }\end{array}$ \\
\hline $\begin{array}{l}\text { The ways of solving complaints } \\
\text { and suggestions }\end{array}$ & $\begin{array}{c}\text { Total Value: Total Score of } \\
\text { Questionnaire }=2,5625\end{array}$ & $\begin{array}{l}\text { Weighted Average }=\text { Average } \\
\text { Value }(\text { NRR) } \times 1=2,5625\end{array}$ & $\begin{array}{c}\text { Total Average Value } \\
\times 25=64,0625\end{array}$ \\
\hline
\end{tabular}

Based on presented data, it was known that public perception level towards One Stop Integrated Service Office of Pamekasan Regency in solving complaints and suggestions on giving license of housing and residential area had total score 64,0625 and weighted average is 2,5625 .

Table 3 - Value of Service Quality Interval

\begin{tabular}{|c|c|c|c|c|c|}
\hline Number & $\begin{array}{c}\text { Perceived } \\
\text { Value }\end{array}$ & $\begin{array}{c}\text { Small and Medium } \\
\text { Industry Interval Value }\end{array}$ & $\begin{array}{c}\text { Service } \\
\text { Quality Value }\end{array}$ & $\begin{array}{c}\text { Service Quality } \\
\text { Category }\end{array}$ & $\begin{array}{c}\text { Service Unit } \\
\text { Performance }\end{array}$ \\
\hline 1. & 1 & $1,0000-2,5996$ & $25,00-64,99$ & D & Very Poor \\
\hline 2. & 2 & $2,6000-3,0640$ & $65,00-76,60$ & C & Poor \\
\hline 3. & 3 & $3,0644-3,5320$ & $76,61-88,30$ & B & Good \\
\hline 4. & 4 & $3,5324-4,0000$ & $88,31-100,00$ & A & Very good \\
\hline
\end{tabular}

Source: Permenpan Number 14 of 2017.

The service of solving complaints and suggestions on giving license of housing and residential area offered by Investment and One Stop Integrated Service Office of Pamekasan Regency was categorized as poor service with total average value of 2, 5625 .

\section{CONCLUSION}

Based on the result of research conducted in Investment and One Stop Integrated Service Office of Pamekasan Regency, it was found that the service of solving complaints and suggestions on giving license of housing and residential area had not responded yet. Based on the result on data analysis, it was found that public perception level towards this 
service had total score 64.0625 and weighted average is 2.5625 . It was categorized as poor service. Although the service was poor so far, Investment and One Stop Integrated Service Office at Pamekasan Regency should improve its performance for better service quality.

\section{REFERENCES}

1. Abdurahman. 2018. Capacity Building Aparatur Sipil Negara Untuk Mewujudkan Democratic Local Governance. Univeritas Airlangga. Surabaya.

2. Sinambela, Lijan Poltak. Dkk. 2011. Reformasi Pelayanan Publik. Bumi Aksara. Jakarta.

3. Sugiyono. 2011. Metode Penelitian Kuantitatif, Kualitatif, and R\&D. Alfabeta. Bandung.

4. Krejcie, R. V., \& Morgan, D. W. 1970. Determining Sample Size for Research Activities. Educational and Psychological Measurement.

5. (2017) Peraturan Menteri Pendayagunaan Aparatur Negara and Reformasi Birokrasi Republik Indonesia Nomor 14 Tahun 2017 Tentang Pedoman Penyusunan Survei Kepuasan Masyarakat Unit Penyelenggara Pelayanan Publik. 